九州大学学術情報リポジトリ

Kyushu University Institutional Repository

\title{
The Link Between Renewable Energy Use and Energy Poverty: Panel Estimation For South Asian Region
}

Md. Matiar Rahman

International Institute for Carbon-Neutral Energy Research (WPI-I2CNER), Kyushu University

Hosan, Shahadat

International Institute for Carbon-Neutral Energy Research (WPI-I2CNER), Kyushu University

Shamal Chandra Karmaker

International Institute for Carbon-Neutral Energy Research (WPI-I2CNER), Kyushu University

Abu Zar Md. Shafiullah

Department of Statistics, University of Dhaka

他

https://doi.org/10.5109/4738588

出版情報: Proceedings of International Exchange and Innovation Conference on Engineering \& Sciences (IEICES). 7, pp. 198-203，2021-10-21. 九州大学大学院総合理工学府

バージョン:

権利関係 : 


\title{
The Link Between Renewable Energy Use and Energy Poverty: Panel Estimation For South Asian Region
}

\author{
Md. Matiar Rahman ${ }^{1,3}$, Shahadat Hosan ${ }^{1,2}$, Shamal Chandra Karmaker ${ }^{1,2,3}$, Abu Zar Md. Shafiullah ${ }^{3}$ and Bidyut Baran \\ Saha $^{1,2^{*}}$ \\ ${ }^{1}$ International Institute for Carbon-Neutral Energy Research (WPI-I2CNER), Kyushu University, 744 Motooka, Nishi-ku, \\ Fukuoka-shi, Fukuoka 819-0395, Japan \\ ${ }^{2}$ Mechanical Engineering Department, Kyushu University, 744 Motooka, Nishi-ku, Fukuoka-shi, Fukuoka 819-0395, \\ Japan \\ ${ }^{3}$ Department of Statistics, University of Dhaka, Dhaka-1000, Bangladesh \\ *Corresponding author email: saha.baran.bidyut.213@m.kyushu-u.ac.jp
}

\begin{abstract}
The incapability of people to have sufficient access to energy sources is known as energy poverty. It is a multifaceted and complex problem. This research looks into how renewable energy use, economic growth, urbanization, employment, and the consumer price index are all linked to energy poverty in South Asian nations. The relationship between the analyzed factors in this region has not been thoroughly investigated so far. As a result, the goal of this research is to look at the dynamic relationships between these variables in the most energy-intensive countries of South Asia using advanced econometric methods for the years 2000 to 2020. This analysis imply that renewable energy reduces energy poverty. Furthermore, energy poverty is inversely correlated with economic growth and employment, but positively associated with urbanization. The findings provide a foundation for energy policymakers that would help them to achieve the objective of Sustainable Development Goals (SDGs).
\end{abstract}

Keywords: CCEMG; Energy poverty; Panel cointegration; Renewable energy; South Asia

\section{INTRODUCTION}

Energy poverty has a significant impact on both the global and local levels, and it is still a relatively new topic on the international arena. Because of its strong links to absolute poverty, climate change, gender inequality, and economic progress, energy poverty is becoming an emerging issue [1]. Energy poverty has been defined as a "state of inability to actualize critical capacities due to a lack of appropriate access to affordable, effective, adequate, quality, and secure energy services" (ibid)[2]. According to Sen et al. [3], poverty is defined as the lack of possibilities for living a basic human life. Different sources, such as González-Eguino [4] and the European Poverty Observatory [5], include crucial individual requirements such as food, warmth, livelihoods, health, and education, among others.

Many researchers have highlighted the prevalence of energy poverty in specific nations with low economic growth [6]. Boardman [7] was the first to propose the phrase "energy poverty", claiming that a household is "energy-poor" if its energy expenditure exceeds $10 \%$ of its annual income. Energy poverty has since been linked to limited fuel access and the security of affordable and accessible heat in affluent countries, according to subsequent studies. The impact of renewable energy resources in easing energy poverty in Palestine was investigated by Hamed et al. [1]. They discovered that in Palestine, poverty and energy poverty are linked. Ssennono et al. [2] used a multidimensional energy poverty index to investigate energy poverty in Uganda. The M-Gamma method demonstrates considerable disparity distribution by gender, regional location, and residence, indicating that energy poverty does not follow a uniform distribution. Rahman et al. [8] investigated the impact of remittance on energy consumption in South Asian nations using panel analysis and observed that remittance had a considerable beneficial impact on energy consumption. For a panel data analysis of developing nations, Nicholas et al. [9] examined on energy poverty and education. Education, they discovered, has a detrimental impact on energy poverty.
France [10], Ireland [11], Greece [12-14], Germany [15], New Zealand [16], Austria [17], Denmark [18], Spain [19], and Italy [20] have all investigated energy poverty on a national, regional, and local level.

The integration of renewable energy into electrical systems, according to energy poverty experts, alleviates energy poverty. For example, a number of studies in Southeast Asia and Sub-Saharan Africa have looked into the environmental and social effects of using renewable energy to electrify rural communities [21-23]. Furthermore, there is no panel analysis of the relationship across energy poverty, renewable energy consumption, economic growth, employment, urbanization, and the consumer price index. These studies all agree that expanding renewable energy consumption will help to alleviate energy poverty while also reducing potential greenhouse gas emissions.

To fill this knowledge vacuum, we are doing a study in South Asia to see how renewable energy usage is linked to energy poverty, considering economic growth, employment, demographic implications (i.e., urbanization), and the consumer price index as a control variable. This 'renewable energy use-energy povertygrowth' nexuses were studied utilizing a panel cointegration approach based on common correlated effects mean group (CCEMG) approaches, which boost statistical power substantially. The CCEMG findings show that renewable energy consumption has a negative influence on energy poverty, indicating that as renewable energy use rises, energy poverty reduces in the long-run, and the association is statistically significant at the $10 \%$ level of significance.

\section{MODEL USED AND DATA}

\subsection{Econometric model}

Using the aforementioned context and literature, we apply the following model to analyze the relationship between energy poverty and renewable energy use, with economic growth, urbanization, employment, and the consumer price index as control variables. We used 
principal component analysis (PCA) to develop an energy poverty index. Equation (1) describes the model's function:

$$
E P_{i t}=f\left(R E_{i t}, E G_{i t}, E M P_{i t}, U P_{i t}, C P I_{i t}\right)
$$

EP stands for energy poverty index, which is calculated using principal component analysis that includes access to electricity as well as clean fuels and cooking technologies; RE stands for renewable energy use; EG stands for economic growth, EMP for employment, UP for urbanization, and CPI stands for consumer price index. The link across variables of interest is discovered using a basic multivariate framework. Except for the major component scores of energy poverty, we smooth the data by converting all series to their natural logarithm (EP). In comparison to a basic linear technique, this conversion helps to reduce autocorrelation and heteroscedasticity concerns while also offering more accurate and dependable findings. The model is shown in $\log$-linear form in Equation (2):

$$
\begin{gathered}
E P_{i t}=\alpha_{0}+\beta_{1} \ln R E_{i t}+\beta_{2} \ln E G_{i t}+\beta_{3} \ln E M P_{i t} \\
+\beta_{4} \ln U P_{i t}+\beta_{5} \ln C P I_{i t}+u_{i t}
\end{gathered}
$$

Cross-sections (nations) and time (year) are represented by $i(1 \ldots \ldots, \mathrm{N})$, and $t(1 \ldots \ldots, \mathrm{T})$, respectively. $\alpha_{0}$ indicates the intercept of the model, $\beta_{1}$ are the coefficients of the renewable energy use. The coefficients $\beta_{2}, \beta_{3} \ldots \ldots \ldots, \beta_{5}$ represent for economic growth, employment, urbanization, and consumer price index, respectively. $u_{i t}$ is the random error term in the model. The coefficients $\beta_{1}$, i.e., the relationship between energy poverty and renewable energy use, are at the core of our work.

\subsection{Data sources}

For five South Asian countries, annual panel data was collected from 2000 to 2020. Bangladesh, India, Sri Lanka, Nepal, and Pakistan are among the most energy use countries. The variables used in this study are per capita gross domestic product (GDP) as an indicator of economic growth, and energy poverty (EP) is measured using a PCA score based on access to electricity and clean fuels and cooking technology. Figure 1 shows the eigenvalues of the energy poverty index. The variable RE denotes the amount of renewable energy consumed. The variable employment represents the employment-topopulation ratio, 15+, total; urbanization is the percentage of the population who lives in a city, and finally used consumer price index considering 2010 as a base year.

The five nations in South Asia included in this study were chosen based on the availability of data for all variables. In this study, $\mathrm{N}^{*} \mathrm{~T}=105$ observations were examined, with $\mathrm{N}=5$ and $\mathrm{T}=21$. The World Bank published the World Development Indicators (WDI), which provided data of all variables [24]. Since renewable energy use data for all countries were available up to the year 2015 in the WDI, the data for this variable of the years 20162020 was taken from national level energy poverty reports. Notation of the variables with data sources are presented in Table 1. The descriptive statistics for the variable in this study are shown in Table 2.

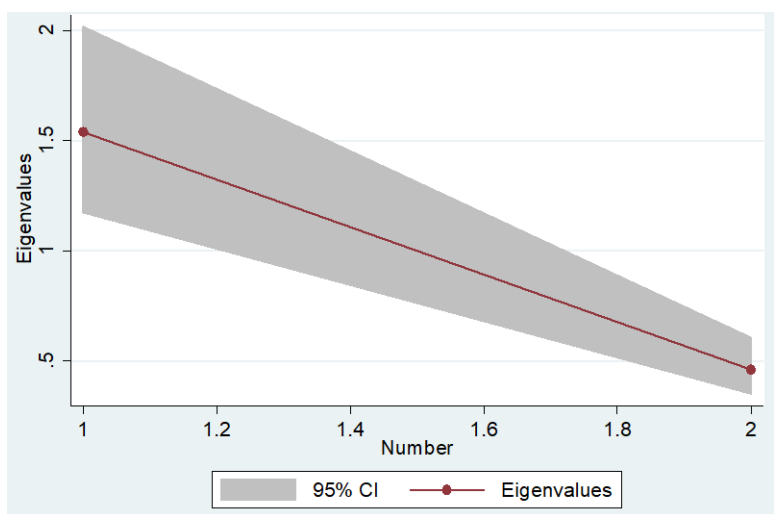

Fig. 1. Scree plot of the eigenvalues for the PCA of

\begin{tabular}{|c|c|c|}
\hline $\begin{array}{c}\text { Variable and } \\
\text { notations }\end{array}$ & Measure & $\begin{array}{c}\text { Data } \\
\text { sources }\end{array}$ \\
\hline $\begin{array}{c}\text { GDP per } \\
\text { capita (EG) }\end{array}$ & Current US\$ & WDI \\
\hline $\begin{array}{l}\text { Renewable } \\
\text { energy use } \\
\quad(\mathrm{RE})\end{array}$ & $\begin{array}{l}\text { Consumption of renewable } \\
\text { energy ( } \% \text { of total final } \\
\text { energy consumption) }\end{array}$ & WDI \\
\hline \multirow[t]{2}{*}{$\begin{array}{l}\text { Energy } \\
\text { poverty (EP) } \\
\text { (PCA score) }\end{array}$} & $\begin{array}{l}\text { Electricity access (E- } \\
\text { access) (\% of total } \\
\text { population) }\end{array}$ & WDI \\
\hline & $\begin{array}{c}\text { Clean fuels and } \\
\text { technologies used in } \\
\text { cooking (Cook-access) }(\% \\
\text { of total population) }\end{array}$ & WDI \\
\hline $\begin{array}{l}\text { Employment } \\
\text { (EMP) }\end{array}$ & $\begin{array}{l}\text { Population employment } \\
\text { ratio, } 15+\text {, total }(\%)\end{array}$ & WDI \\
\hline $\begin{array}{l}\text { Urban } \\
\text { population } \\
\text { (UP) }\end{array}$ & $\begin{array}{c}\% \text { of population in urban } \\
\text { area }\end{array}$ & WDI \\
\hline $\begin{array}{l}\text { Consumer } \\
\text { price index } \\
(\mathrm{CPI})\end{array}$ & $\begin{array}{l}\text { Consumer price index } \\
\text { taking } 2010 \text { as } 100\end{array}$ & WDI \\
\hline
\end{tabular}
energy poverty.

Table 1. Summary of the variables and data.

WDI: World development indicators

Table 2. Descriptive measurement of the variables

\begin{tabular}{lcclcl}
\hline \hline Variable & Obs. & Mean & $\begin{array}{l}\text { Std. } \\
\text { Dev }\end{array}$ & Min & Max \\
\hline E-access & 105 & 71.55 & 17.65 & 24.6 & 100.0 \\
Cook- & 105 & 25.45 & 10.05 & 7.24 & 47.26 \\
access & & & & & \\
RE & 105 & 55.28 & 17.79 & 32.12 & 91.31 \\
EG & 105 & 1270 & 950.2 & 229.4 & 4076 \\
UP & 105 & 26.37 & 7.78 & 13.39 & 38.17 \\
EMP & 105 & 57.94 & 12.00 & 43.00 & 84.25 \\
CPI & 105 & 106.0 & 45.40 & 36.48 & 200.0 \\
\hline
\end{tabular}

\section{METHODOLOGY}

Advanced econometric approaches are employed in this work to investigate the long-run and dynamic causality connecting energy poverty, renewable energy consumption, economic growth, urbanization, employment, and the consumer price index. The steps in the methodologies are as follows: 1) a test of crosssectional dependency 2) CIPS and CADF, which are second-generation panel unit root tests. 3) panel cointegration tests, such as the Kao, Pedroni, and 
Westerlund methods. 4) parameter estimation with common correlated effects means group (CCEMG).

\subsection{Cross-sectional dependence tests}

The cross-sectional dependency problem in panel data could be triggered by the relationship and dependence across countries as a result of globalization and economic interaction [25]. The study conclusions from such approaches may be skewed if the existence of crosssection dependency is not taken into account in the panel [26-28]. As a result, in order to address this issue in the research, we performed cross-sectional dependence (CD) tests. The cross-section dependence is determined using Breusch and Pagan's [29] LM test and Pesaran's [30] CD test. Cross-sectional units are assumed to be independent in the null hypothesis, but cross-sectional units are assumed to be dependent in the alternative hypothesis. The following equation is used to determine the Breusch and Pagan LM test results:

$$
L M_{B P}=T \sum_{i=1}^{N-1} \sum_{j=i+1}^{N} \hat{\zeta}_{i j}^{2}
$$

If the value of $\mathrm{T}$ is relatively large, the $\mathrm{LM}$ test is ineffective. Pesaran suggests the following CD test as an alternative to solving this problem:

$$
C D_{P}=\sqrt{\frac{2 T}{N(N-1)}}\left(\sum_{i=1}^{N-1} \sum_{j=i+1}^{N} \hat{\zeta}_{i j}^{2}\right)
$$

Where $T$ denotes the year, $N$ is the number of countries, and $\hat{r}_{i j}^{2}$ indicates the relationship between the error in Eq. (3) and Eq. (4).

\subsection{Unit root tests}

To establish the order of data, unit root analysis is used [28,31]. This method detects if a series is stationary or not (unit root). CIPS and CADF, the second-generation panel unit root tests, are used to solve cross-sectional dependency and produce the most flawless and consistent findings. According to Pesaran [32], cross-section augmented Dickey-Fuller (CADF) analysis is defined as follows:

$$
\Delta Z_{i t}=A_{i}+B_{i} Z_{i, t-1}+C_{i} \bar{Z}_{t-1}+C_{i} \Delta \bar{Z}_{t}+u_{i t}
$$

Where $\mathrm{Z}$ measures the target variable, $\Delta$ indicates the difference operator, and $u_{i t}$ is the residual term. Using CADF, Pesaran established the cross-section augmented IPS (CIPS) test:

$$
C I P S=1 / N \sum_{i=1}^{N} C A D F_{i}
$$

The null hypothesis states that each the variable has a unit root, as opposed to the alternative hypothesis, which states that all panel within a variable are not unit root.

\subsection{Panel cointegration test}

If the unit root tests show that the series is non-stationary, a panel cointegration test is used to determine the longterm connection between the variables [33]. The cointegration methods employed in the study include Pedroni [34,35], Kao [36], and Westerlund [37].
As shown in Equation 7, the tests outlined above are based on residuals computed from the long-run model:

$$
y_{i t}=\alpha_{i}+\tau_{i} t+\sum_{j=1}^{m} \gamma_{j i} x_{j i t}+u_{i t}
$$

In Eq. 7, the cross-section units, number of predictors, and number of cases are represented by $i(1,2, \ldots . N) ; j$ $(1,2, \ldots . m)$ and $t(1,2, \ldots ., T) . \quad y$ and $x$ are regarded to be first order integrated. The coefficients $\tau_{i}, \alpha_{i}$, and $\gamma_{j i}$ expressed as trend effect, intercept, and slope, respectively, and $\boldsymbol{u}_{i t}$ is the random errors. Eq. (8) can be used to show the estimated residuals:

$$
\varepsilon_{i t}=\rho_{i} u_{i t-1}+\omega_{i t}
$$

The null hypothesis in the preceding test is Ho: $\rho_{i}=1$, which implies that there is no cointegration, as opposed to the alternative $\left(\mathrm{H}_{1}: \rho_{\mathrm{i}}<1\right)$, which specifies that all panels are cointegrated.

\subsection{Estimation of long run coefficient}

Long-run parameters must be estimated after confirming that the variables are cointegrated. CCEMG (common correlated effects mean group) [38] can be used to measure long-run characteristics. The CCEMG estimator is resistant to structural breaks and unobserved nonstationary common components. As a result, in this work, the CCEMG technique is used to estimate the parameters of the examined relationships. The CCEMG use the following method for estimating:

$$
y_{i t}=\alpha_{i}+\beta_{i} x_{i t}+\delta_{i} \bar{y}_{i t}+\tau_{i} \bar{x}_{i t}+\varphi_{i} f_{t}+\varepsilon_{i t}
$$

The dependent variable is $y_{i t}$, the independent variable is $x_{i t}$, the slope of the exogenous component is $\beta_{i}$, the group fixed effects are $\alpha_{i}$, the unobserved common factor is $f_{t}$, and the residual is $\varepsilon_{\mathrm{it}}$. As seen below, the CCEMG estimator is developed by taking the average of each coefficient over each individual regression:

$$
C C E M G=1 / N \sum_{i=1}^{N} \widehat{\beta}_{i}
$$

Where $\hat{\beta}_{i}$ is the expected value of $\beta_{i}$ from Eq.(9).

\section{RESULTS AND DISCUSSION}

All findings based on indicated methodological approaches are reported in this section. In addition, Table 3 shows the cross-section dependence test results.

Table 3. The results of cross-section dependency.

\begin{tabular}{ccc}
\hline \hline Variables & $\begin{array}{c}\text { LM test } \\
\text { Test Statistic }\end{array}$ & $\begin{array}{c}\text { CD test } \\
\text { Test Statistic }\end{array}$ \\
\hline EP & $7261.351^{* * *}$ & $88.267^{* * *}$ \\
lnRE & $5356.254^{* * *}$ & $64.351^{* * *}$ \\
lnEG & $4567.253^{\text {*** }}$ & $85.362^{* *}$ \\
lnEMP & $3651.985^{\text {*** }}$ & $29.364^{* *}$ \\
lnUP & $3516.354^{\text {*** }}$ & $46.182^{* *}$ \\
lnCPI & $3641.124^{* * *}$ & $18.364^{* *}$ \\
\hline
\end{tabular}

Using the associated p-values of LM and CD test statistics in table 3 , the null hypothesis of cross-sectional independence can be rejected for energy poverty, renewable energy use, economic growth, employment, urbanization, and consumer price index. As a result, 
cross-section dependence exists for all variables in our study.

Before analyzing cointegration, it is crucial to identify whether or not the data are non-stationary. The CIPS and CADF tests were utilized in this work to detect unit roots in the variables under investigation. The results of these two tests are summarized in Table 4.

Table 4. the results of panel unit root test.

\begin{tabular}{lllll}
\hline \hline Variable & CIPS & & CADF \\
& Level & 1st diff. & Level & 1st diff. \\
\hline EP & -3.536 & $-6.264^{* * * *}$ & -3.573 & $-5.106^{* *}$ \\
$\operatorname{lnRE}$ & -3.053 & $-3.367^{* * * *}$ & $-6.26^{* *}$ & $-8.36^{* * *}$ \\
$\operatorname{lnEG}$ & $-3.815^{* *}$ & $-4.337^{* *}$ & -2.556 & $-3.287^{* *}$ \\
$\operatorname{lnEMP}$ & $-1.181^{*}$ & $-4.801^{* *}$ & -2.185 & $-4.531^{* *}$ \\
$\operatorname{lnUP}$ & -1.650 & $-2.831^{*}$ & -2.477 & $-4.200^{*}$ \\
$\operatorname{lnCPI}$ & $-4.090^{*}$ & $-2.690^{* *}$ & -8.034 & $-9.795^{* *}$ \\
\hline
\end{tabular}

Significant at ( $\left.10 \%{ }^{* *} 5 \%,{ }^{* * *} 1 \%\right)$ level.

According to the hypothesis, the variables are nonstationary, as shown by the results in Table 4 . The hypothesis is not rejected at the level in both cases, but the first difference demonstrates significance at the $1 \%$ level. As a result, according to the CIPS and CADF tests, all of the variables have a unit root at the level; however, none of the variables have a unit root at the first difference, which is of degree one I. (1).

Because all of the variables in Eq. (5) were in the I (1) process, the panel cointegration approach was utilized to determine the long-run linkages between them. The results of Pedroni [34,35] and Westerlund [37] are shown in Table 5.

Table 5. Results of panel cointegration tests.

\begin{tabular}{cc}
\hline Approaches & t-value \\
\hline Pedroni (1999, 2004) & \\
Modified Phill-Perron t & $5.3654^{* *}$ \\
Phill-Perron t & $-5.2351^{* *}$ \\
Aug. D-Fuller t & $-2.2541^{* * *}$ \\
Westerlund (2005) & $3.2654^{* *}$ \\
\hline Variance ratio & $\left.{ }^{* * *} 1 \%\right)$.
\end{tabular}

In these tests, the null hypothesis is that there is no cointegration in the panel. Table 5 reveals that the variables studied have a long-term relationship, rejecting the null hypothesis with a 5\% significance level. This finding explains why all of the variables in the study are cointegrated. The CCEMG approach is used to estimate the long-run coefficients in this study, and the results are shown in Table 6.

Table 6. Estimation of coefficients of CCEMG method.

\begin{tabular}{cccc}
\hline \hline variables & coefficients & Std. error & p-value \\
\hline $\ln R E$ & $-0.2249^{*}$ & 0.2041 & 0.085 \\
$\operatorname{lnEG}$ & $-0.0765^{*}$ & 0.1627 & 0.077 \\
$\operatorname{lnEMP}$ & $-1.0051^{*}$ & 0.7390 & 0.086 \\
$\ln \mathrm{*P}$ & $3.698^{* *}$ & 1.9607 & 0.045 \\
$\operatorname{lnCPI}$ & -0.0294 & 0.3298 & 0.226 \\
\hline
\end{tabular}

Significant at ${ }^{*} 10 \%{ }^{* *} 5 \%,{ }^{* * *} 1 \%$ level.

The CCEMG findings show that renewable energy consumption has a negative influence on energy poverty, indicating that as renewable energy use rises, energy poverty falls, and the association is statistically significant at the $10 \%$ level of significance. The finding of the study is desired. Other control variables, such as economic growth and employment, have a negative impact on energy poverty, implying that as GDP and the number of employees rise, so does energy poverty. On the other hand, urbanization has a positive and statistically significant impact on energy poverty, indicating that urbanization and energy poverty are proportionally related. This method also reveals that a country's consumer price index and energy poverty have a reciprocal relationship.

Fig. 2 depicts the long-run causalities of the variables studied.

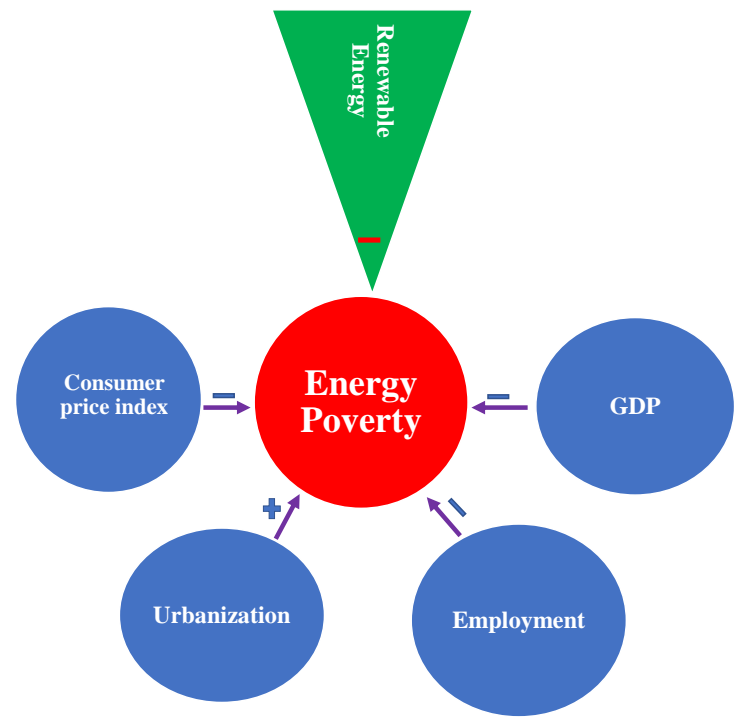

Fig. 2. The long-run causality among studied variables.

The findings of the CCEMG investigation showed longrun relationships, with implications for researchers and policymakers on how to effectively realize the prospects to eliminate energy poverty by utilizing renewable energy in the energy sector to increase economic performance in the digital economy era.

\section{CONCLUSIONS IMPLICATIONS}

AND

POLICY

This study discusses at the link between renewable energy use and energy poverty in South Asian countries taking data from 2000 to 2020, considering economic growth, employment, urbanization, and the consumer price index as a control variable. To diagnose the causal relationship between underlying variables, we used second generation unit root tests, the Westerlund cointegration technique, and the CCEMG estimation in this research. Renewable energy consumption, economic growth, and employment all appear to have a negative impact on energy poverty, according to the data. Urbanization, on the other hand, exacerbates energy poverty in Southeast Asian nations.

Access to sustainable energy is the key component of economic growth, according to policy guidelines for Southeast Asian nations, and access to renewable and modern forms of energy is an "important precondition" in combating energy poverty, promoting economic growth, enhancing employment opportunities, and 
supporting foundational social services. Focusing on South Asian economies' policy instruments is critical for lowering obstacles to renewable energy adoption, and it is the golden thread that will bind economic growth, development, and environmental sustainability together.

\section{REFERENCES}

[1] T.A. Hamed, K. Peric, The role of renewable energy resources in alleviating energy poverty in Palestine, Renew. Energy Focus. 35 (2020) 97107. https://doi.org/10.1016/j.ref.2020.09.006.

[2] V. Fred, J.M. Ntayi, F. Buyinza, F. Wasswa, M. Aarakit, C. Ndatira, Energy poverty in Uganda : Evidence from a multidimensional approach, Energy Econ. $101 \quad$ (2021) 105445. https://doi.org/10.1016/j.eneco.2021.105445.

[3] A. Sen, Poverty: An Ordinal Approach to Measurement, Econometrica. 44 (1976) 219. https://doi.org/10.2307/1912718.

[4] M. González-Eguino, Energy poverty: An overview, Renew. Sustain. Energy Rev. 47 (2015) 377-385.

https://doi.org/10.1016/j.rser.2015.03.013.

[5] S. Bouzarovski, H. Thomson, M. Cornelis, Confronting energy poverty in europe: A research and policy agenda, Energies. 14 (2021) 1-19. https://doi.org/10.3390/en14040858.

[6] H.U.R. Khan, K. Zaman, S.U. Yousaf, A.M. Shoukry, S. Gani, M.A. Sharkawy, Socioeconomic and environmental factors influenced pro-poor growth process: new development triangle, Environ. Sci. Pollut. Res. 26 (2019) 29157-29172. https://doi.org/10.1007/s11356019-06065-2.

[7] B. Brenda, Fuel poverty: from cold homes to affordable warmth, Printer Pub Limited, 1991.

[8] M.M. Rahman, S. Hosan, S.C. Karmaker, A.J. Chapman, B.B. Saha, The effect of remittance on energy consumption: Panel cointegration and dynamic causality analysis for South Asian countries, Energy. $220 \quad$ (2021) 119684. https://doi.org/10.1016/j.energy.2020.119684.

[9] L. Yijing, Y. Su, Y. Lin, L. He, L. Wu, X. Hou, C. Zheng, Energy Poverty and Education: Fresh Evidence from a Panel of Developing Countries, Build. Environ. $184 \quad$ (2020) 107229. https://doi.org/10.1016/j.eneco.2021.105430.

[10] B. Legendre, O. Ricci, Measuring fuel poverty in France: Which households are the most fuel vulnerable?, Energy Econ. 49 (2014) 620-628. https://doi.org/10.1016/j.eneco.2015.01.022.

[11] J.D. Healy, J. Peter Clinch, Fuel poverty, thermal comfort and occupancy: Results of a national household - survey in Ireland, Appl. Energy. 73 (2002) 329-343. https://doi.org/10.1016/S03062619(02)00115-0.

[12] L. Papada, D. Kaliampakos, Measuring energy poverty in Greece, Energy Policy. 94 (2016) 157-165.

https://doi.org/10.1016/j.enpol.2016.04.004.

[13] N.M. Katsoulakos, D.C. Kaliampakos, Mountainous areas and decentralized energy planning: Insights from Greece, Energy Policy. $91 \quad$ (2016) 174-188. https://doi.org/10.1016/j.enpol.2016.01.007.

[14] M. Santamouris, J.A. Paravantis, D. Founda, D. Kolokotsa, P. Michalakakou, A.M. Papadopoulos, N. Kontoulis, A. Tzavali, E.K. Stigka, Z. Ioannidis, A. Mehilli, A. Matthiessen, E. Servou, Financial crisis and energy consumption: A household survey in Greece, Energy Build. 65 (2013) 477-487. https://doi.org/10.1016/j.enbuild.2013.06.024.

[15] M.S. Gmbh, Measuring Fuel Poverty: General Considerations and Application to German Household Data, FinanzArchiv. 71 (2015) 178. https://doi.org/10.1628/001522115x1428572352 7593.

[16] R. Lawson, J. Williams, B. Wooliscroft, Contrasting approaches to fuel poverty in New Zealand, Energy Policy. 81 (2015) 38-42. https://doi.org/10.1016/j.enpol.2015.02.009.

[17] K.M. Brunner, M. Spitzer, A. Christanell, Experiencing fuel poverty. Coping strategies of low-income households in Vienna/Austria, Energy Policy. 49 (2012) 53-59. https://doi.org/10.1016/j.enpol.2011.11.076.

[18] S.C.A. Nierop, Energy Poverty in Denmark?, (2014) 52.

[19] E. Phimister, E. Vera-Toscano, D. Roberts, The dynamics of energy poverty: Evidence from Spain, Econ. Energy Environ. Policy. 4 (2015) 153-166. https://doi.org/10.5547/21605890.4.1.ephi.

[20] R. Miniaci, C. Scarpa, P. Valbonesi, Energy affordability and the benefits system in Italy, Energy Policy. 75 (2014) 289-300. https://doi.org/10.1016/j.enpol.2014.09.008.

[21] D. Roberts, E. Vera-Toscano, E. Phimister, Fuel poverty in the UK: Is there a difference between rural and urban areas?, Energy Policy. 87 (2015) 216-223.

https://doi.org/10.1016/j.enpol.2015.08.034.

[22] G.D. Kamalapur, R.Y. Udaykumar, Rural electrification in India and feasibility of Photovoltaic Solar Home Systems, Int. J. Electr. Power Energy Syst. 33 (2011) 594-599. https://doi.org/10.1016/j.ijepes.2010.12.014.

[23] D. Palit, Solar energy programs for rural electrification: Experiences and lessons from South Asia, Energy Sustain. Dev. 17 (2013) 270 279. https://doi.org/10.1016/j.esd.2013.01.002.

[24] B. World, Data Bank: World Development Indicators, (2019).

[25] S.C. Karmaker, S. Hosan, B.B. Saha, Does biomass energy consumption improve human development? Evidence from South Asian countries, Int. Energy J. 21 (2021) 81-92.

[26] M. Aydin, The effect of biomass energy consumption on economic growth in BRICS countries: A country-specific panel data analysis, Renew. Energy. 138 (2019) 620-627. https://doi.org/10.1016/j.renene.2019.02.001.

[27] Z. Wang, Q. Bui, B. Zhang, The relationship between biomass energy consumption and human development: Empirical evidence from BRICS countries, Energy. 194 (2020) 116906. 
https://doi.org/10.1016/j.energy.2020.116906.

[28] S. Chandra Karmaker, S. Hosan, A.J. Chapman, B.B. Saha, The role of environmental taxes on technological innovation, Energy. 232 (2021) 121052. https://doi.org/10.1016/j.energy.2021.121052.

[29] T.S. Breusch, A.R. Pagan, The Lagrange Multiplier Test and its Applications to Model Specification in Econometrics, Rev. Econ. Stud. 47 (1980) 239. https://doi.org/10.2307/2297111.

[30] M.H. Pesaran, General Diagnostic Tests for Cross Section Dependence in Panels, Univ. Cambridge USC. 3 (2004) Working Paper No.0435, June 2004.

[31] S. Hosan, Md. Matiar Rahman, Shamal Chandra Karmaker, Bidyut Baran Saha, The Effect of Technological Innovation on Environmental Quality: Accounting Ecological Footprint Indicators for Asian Countries, Proc. Int. Exch. Innov. Conf. Eng. Sci. 6 (2020) 198-203. https://doi.org/10.5109/4102488.

[32] M.H. Pesaran, A simple panel unit root test in the presence of cross-section dependence, J. Appl. Econom. $22 \quad$ (2007) 265-312. https://doi.org/10.1002/jae.951.

[33] Shamal Chandra Karmaker, Md. Matiar Rahman, S. Hosan, Bidyut Baran Saha, The Impact of Biomass Energy Consumption on Human
Development: Evidence from Asian Countries, Proc. Int. Exch. Innov. Conf. Eng. Sci. 6 (2020) 204-211. https://doi.org/10.5109/4102489.

[34] P. Pedroni, Panel cointegration: Asymptotic and finite sample properties of pooled time series tests with an application to the PPP hypothesis, Econom. Theory. 20 (2004) 597-625. https://doi.org/10.1017/S0266466604203073.

[35] P. Pedroni, Critical Values for Cointegration Tests in Heterogeneous Panels with Multiple Regressors, Oxf. Bull. Econ. Stat. 61 (1999) 653-670. https://doi.org/10.1111/14680084.61.s1.14.

[36] C. Kao, Spurious regression and residual-based tests for cointegration in panel data, J. Econom. 90 (1999) 1-44. https://doi.org/10.1016/S03044076(98)00023-2.

[37] J. Westerlund, New simple tests for panel cointegration, Econom. Rev. 24 (2005) 297-316. https://doi.org/10.1080/07474930500243019.

[38] M.H. Pesaran, Estimation and inference in large heterogeneous panels with a multifactor error structure, Econometrica. 74 (2006) 967-1012. https://doi.org/10.1111/j.14680262.2006.00692.x. 